\title{
Relationship between Egg Fertility and Testes Weight and Semen Characteristics in Japanese Quail Bred by Full-Sib Mating
}

\author{
Katsunori Sato, Susumu Sato and Takayoshi INo \\ Department of Animal Science, Faculty of Agriculture, \\ Okayama University, Okayama-shi 700
}

(Received July 27, 1983)

\begin{abstract}
In order to elucidate the cause of the reduction in egg fertility in Japanese quail by inbreeding, the relationship between the reduced egg fertility and male reproductive ability was investigated in this study. Japanese quail used in this experiment consisted of the first and second generations in full-sib and random mating groups. 1. The egg fertility in the full-sib mating group was reduced rapidly in the second generation, presenting a significant difference from the random mating group. 2 . The testes weight, semen volume, sperm concentration and sperm motility were all reduced in the full-sib mating group as compared with those in the random mating group, while the percentage of abnormal sperms was higher in the former group. However, no difference existed in the semen $\mathrm{pH}$ level between these groups. 3. The high egg fertility group (above $80.1 \%$ ) showed higher values of testes weight, semen volume, sperm concentration and sperm motility as well as a lower percentage of abnormal sperms, than the low egg fertility group (below 40.0\%). 4. The egg fertility was significantly correlated with testes weight, +0.535 , with semen volume, +0.547 , with sperm concentration, +0.824 , with sperm motility, +0.875 and with the percentage of abnormal sperms, -0.862 . 5. These results indicate that the reduction in egg fertility by inbreeding results from an overall reduction or disorder in male reproductive ability.
\end{abstract}

Jpn. J. Zootech. Sci., 55 (1): 45-51, 1984

The reduction of egg fertility in Japanese quail (Coturnix coturnix japonica) by inbreeding was first investigated by SitTManN et al. ${ }^{1)}$, who noted a rapid loss of fertility as a result of inbreeding when the production of inbred lines was attempted by full-sib mating. The above study was followed by several investigators ${ }^{2-9)}$ who likewise confirmed the rapid reduction in fertility after continued inbreeding. Although the reduction of egg fertility is suspected to be caused by both male and female factors such as morphological and functional abnormalities of spems as well as ova, very little is known of the relationship between the reduction in egg fertility by inbreeding and male reproductive ability.

The present experiment was undertaken to investigate the cause of the reduction in egg fertility by full-sib mating in relation to testes weight and semen characteristics.

\section{Materials and Methods}

Japanese quail used in this study consisted of a full-sib mating group and a random mating group which originated from the control population maintained by 
random mating at the Laboratory of Animal Breeding of the Faculty of Agriculture, Okayama University. Used in this experiment were the eggs obtained from 25 families in the first and 21 families in the second generations of the full-sib mating group, and 20 families in the first and 17 families in the second generations of the random mating group, as well as 21 and 17 adult male quail, aged 20 weeks, in the second generation of the full-sib and random mating groups, respectively. Chicks. were brooded by the same method as reported elsewhere ${ }^{9)}$. Eggs were collected daily in the morning and after recording the family name, they were set continuously for the duration of 10 days in an incubator adjusted at $38.3 \pm 0.2^{\circ} \mathrm{C}$.

In this study, egg fertility of the full-sib and random mating groups was first. investigated, followed by an evaluation of the relationship between the egg fertility and male reproductive ability. The egg fertility was determined as the ratio of the number of fertile eggs to the number of eggs set. Fertilization was confirmed macroscopically by the presence of developing embryos on the fourth day of incubation.

Male reproductive ability was evaluated in terms of the testes weight, semen volume, sperm concentration, sperm motility, percentage of abnormal sperms and semen $\mathrm{pH}$. For the determination of the semen volume, semen was collected by the mating method of KoBayashi et al. ${ }^{10)}$ and measured with a $0.1 \mathrm{ml}$ pipette. The sperm concentration was determined in semen diluted 200 -fold in a Ringer's solution, using a hematocytometer. The sperm motility was examined by the standard method and subjectively scored from 0 to 5 , where 0 was defined as the poorest and 5 as the highest in motility ${ }^{11)}$. The percentage of abnormal sperms was calculated for 500 sperms. The semen $\mathrm{pH}$ was measured with a $\mathrm{pH}$ indicator paper (Merck).

For the calculation of correlation coefficients between the egg fertility and the male reproductive indicators (testes weight, semen volume, sperm concentration, sperm motility, percentage of abnormal sperms and semen $\mathrm{pH}$ ), the percentage of egg fertility was converted into arc sin.

\section{Results}

\section{Egg fertility}

Table 1 shows the egg fertility in the first and the second generations of the fullsib and random mating groups. Rapid reduction in egg fertility was noted in the:

Table 1. Number of eggs set, number of fertile eggs and egg fertility in the full-sib and random mating groups

\begin{tabular}{lccccc}
\hline Mating group & Generation & $\begin{array}{c}\text { No. of } \\
\text { families }\end{array}$ & $\begin{array}{c}\text { No. of } \\
\text { eggs set }\end{array}$ & $\begin{array}{c}\text { No. of } \\
\text { fertile eggs }\end{array}$ & $\begin{array}{c}\text { Egg fertility } \\
(\%)\end{array}$ \\
\hline Full-sib & 1 & 25 & 224 & 216 & 96.4 \\
& 2 & 21 & 167 & 113 & $67.7^{* *}$ \\
\hline \multirow{2}{*}{ Random } & 1 & 20 & 180 & 175 & 97.2 \\
& 2 & 17 & 155 & 153 & 98.7 \\
\hline
\end{tabular}

**Significantly different from the random mating group $(\mathrm{P}<0.01)$. 
Egg Fertility and Male Reproductive Ability

Table 2. Number of families by range of egg fertility in the full-sib and random mating groups

\begin{tabular}{|c|c|c|c|c|c|c|c|c|}
\hline \multirow{3}{*}{ Mating group } & \multirow{3}{*}{ Generation } & \multirow{3}{*}{$T^{1)}$} & \multicolumn{6}{|c|}{ Range of egg fertility (\%) } \\
\hline & & & \multicolumn{2}{|c|}{$80.1-100.0$} & \multicolumn{2}{|c|}{$40.1-80.0$} & \multicolumn{2}{|c|}{$0.0-40.0$} \\
\hline & & & $\overline{\mathrm{N}^{2)}}$ & $\%$ & $\mathrm{~N}^{2)}$ & $\%$ & $\mathrm{~N}^{21}$ & $\%$ \\
\hline \multirow{2}{*}{ Full-sib } & 1 & 25 & 23 & 92.0 & 2 & 8.0 & 0 & 0.0 \\
\hline & 2 & 21 & 11 & 52. $4 * *$ & 5 & $23.8^{*}$ & $5(4)^{33}$ & $23.8^{*}$ \\
\hline \multirow{2}{*}{ Random } & 1 & 20 & 19 & 95.0 & 1 & 5.0 & 0 & 0.0 \\
\hline & 2 & 17 & 17 & 100.0 & 0 & 0.0 & 0 & 0.0 \\
\hline
\end{tabular}

1) Total number of families, 2) No. of families, 3) No. of completely infertile families. *, ** Significantly different from the random mating group $(\mathrm{P}<0.05$, $0.01)$.

second generation of the full-sib mating group. The difference in egg fertility between the two mating groups was clearly evident and was statistically significant.

Table 2 shows the range of egg fertility and the number of families by egg fertility range in the two mating groups. Families were divided into high, medium and low groups showing egg fertility ranges of $80.1 \sim 100.0,40.1 \sim 80.0$ and $0.0 \sim 40.0 \%$ as shown in Table 2. The number of families with egg fertility above $80.1 \%$ amounted to only $11(52.4 \%)$ in the second generation of the full-sib mating group, in contrast to $17(100 \%)$ in the random mating group. At the egg fertility range of $40.1 \sim 80.0$ $\%, 5$ families $(23.8 \%)$ were confirmed in the second generation of the full-sib mating group but $0 \%$ in the random mating group. At the egg fertility range below $40.0 \%$, 5 families were confirmed in the second generation of the full-sib mating group, of which 4 families were found completely infertile. The egg fertility after subtraction of these 4 families from the total number of families in the second generation of the full-sib mating group amounted to $83.7 \%$, which was again significantly lower as compared with the random mating group.

2. Testes weight, semen volume, sperm concentration, sperm motility, percentage of abnormal sperm and semen $p H$

Table 3 shows the values of testes weight, semen volume, sperm concentration, sperm motility, percentage of abnormal sperms and semen $\mathrm{pH}$ in the second generation of the full-sib and random mating groups. The testes weight, sperm concentration and sperm motility were significantly lower in the full-sib mating group than in the random mating group, while the percentage of abnormal sperms was significantly higher in the full-sib mating group than in the random mating group. However, there were no differences in the body weight percentage of the testes weight and semen $\mathrm{pH}$ between these mating groups.

3. Relationship between the egg fertility and male reproductive indicators (testes weight, semen volume, sperm concentration, sperm motility, percentage of abnormal sperms and semen $p H$ ) 
Table 3. Testes weight and semen characteristics in the second generation of the full-sib and random mating groups

\begin{tabular}{llcc}
\hline \multicolumn{1}{c}{ Item } & & Full-sib mating & Random mating \\
\hline Number & & 21 & 17 \\
Testes weight & $(\mathrm{g})$ & $2.1 \pm 0.13^{*}$ & $2.5 \pm 0.10$ \\
& & $\left(2.1 \pm 0.13^{1)}\right.$ & $(2.4 \pm 0.09)$ \\
Semen volume & $(\mu 1)$ & $13.0 \pm 1.13^{*}$ & $16.4 \pm 1.28$ \\
Sperm concentration & $\left(\mathrm{millions} / \mathrm{mm}^{3}\right)$ & $0.7 \pm 0.08^{* *}$ & $1.1 \pm 0.07$ \\
Sperm motility & $(0-5)$ & $2.8 \pm 0.22^{*}$ & $3.5 \pm 0.12$ \\
Percentage of & $(\%)$ & $19.0 \pm 4.30^{*}$ & $8.0 \pm 0.30$ \\
$\quad$ abnormal sperms & & $7.7 \pm 0.04$ & $7.7 \pm 0.06$ \\
\hline
\end{tabular}

Mean \pm S. E., 1) Testes weight $/ 100 \mathrm{~g}$ body weight. *.** Significantly different from the random mating group $(P<0.05,0.01)$.

Table 4 shows the relationship between the egg fertility and male reproductive indicators (testes weight, semen volume, sperm concentration, sperm motility, percentage of abnormal sperms and semen $\mathrm{pH}$ ) in the second generation of the full-sib mating group. The testes weights in the families with egg fertility above $80.1 \%$, $40.1 \sim 80.0 \%$ and below $40.0 \%$ were $2.3,1.9$ and $1.6 \mathrm{~g}$, respectively, indicating lower weights in the families with lower egg fertility. The body weight percentage of the testes weight also showed a similar tendency. The semen volume, sperm concentration and sperm motility was highest in the families with egg fertility above $80.1 \%$ and lowest in the families with egg fertility below $40.0 \%$. The appearance of abnormal sperms was most infrequent in the families with egg fertility above $80.1 \%$ and most frequent in the families with egg fertility below $40.0 \%$. However, semen $\mathrm{pH}$ was the same, regardless of the range of egg fertility, without any evidence of abnormal changes in the families with low egg fertility.

Table 4. Relationship between the egg fertility and testes weight and semen charateristics in the second generation of the full-sib mating group

\begin{tabular}{|c|c|c|c|c|}
\hline \multirow{2}{*}{ Item } & & \multicolumn{3}{|c|}{ Range of egg fertility $(\%)$} \\
\hline & & $80.1-100.0$ & $40.1-80.0$ & $0.0-40.0$ \\
\hline Number & & 11 & 5 & 5 \\
\hline Testes weight & $(g)$ & $\begin{array}{c}2.3 \pm 0.11^{\mathrm{a}} \\
(2.4 \pm 0.10)^{2}\end{array}$ & $\begin{array}{c}1.9 \pm 0.25^{\mathrm{ab}} \\
(1.8 \pm 0.20)^{\mathrm{b}}\end{array}$ & $\begin{array}{l}1.6 \pm 0.36^{b} \\
(1.7 \pm 0.40)^{b}\end{array}$ \\
\hline Semen volume & $(\mu \mathbf{l})$ & $15.1 \pm 1.45^{\mathrm{a}}$ & $12.5 \pm 1.19^{a b}$ & $8.7 \pm 2.56^{b}$ \\
\hline $\begin{array}{l}\text { Sperm concentration } \\
\left(\mathrm{millions} / \mathrm{mm}^{\mathrm{g}}\right)\end{array}$ & & $1.0 \pm 0.05^{\mathrm{a}}$ & $0.7 \pm 0.14^{\mathrm{ab}}$ & $1.2 \pm 0.24^{b}$ \\
\hline Sperm motility & $(0-5)$ & $3.5 \pm 0.16^{\mathrm{a}}$ & $2.6 \pm 0.24^{\mathrm{b}}$ & $1.4 \pm 0.24^{c}$ \\
\hline $\begin{array}{l}\text { Percentage of } \\
\text { abnormal sperms }\end{array}$ & $(\%)$ & $8.0 \pm 0.40^{a}$ & $12.5 \pm 1.76^{\mathrm{b}}$ & $49.8 \pm 8.42^{c}$ \\
\hline Semen $\mathrm{pH}$ & & $7.7 \pm 0.05^{\mathrm{a}}$ & $7.7 \pm 0.13^{\mathrm{a}}$ & $7.7 \pm 0.07^{\mathrm{a}}$ \\
\hline
\end{tabular}

Mean \pm S.E., ( ): Testes weight $/ 100 \mathrm{~g}$ body weight. Values with different superscript letters are significantly different $(P<0.05)$. 
Egg Fertility and Male Reproductive Ability

Table 5. Correlation coefficients between the egg fertility, testes weight and semen characteristics in the second generation of the full-sib mating group

\begin{tabular}{lllllll}
\hline \hline \multicolumn{1}{c}{ Item } & $\begin{array}{c}\text { Testes } \\
\text { weight }\end{array}$ & $\begin{array}{c}\text { Semen } \\
\text { volume concentration }\end{array}$ & $\begin{array}{c}\text { Sperm } \\
\text { motility }\end{array}$ & $\begin{array}{c}\text { Spercentage of } \\
\text { abnormal sperms }\end{array}$ & $\begin{array}{c}\text { Semen } \\
\text { pH }\end{array}$ \\
\hline Egg fertility & $0.535^{*}$ & $0.547^{*}$ & $0.824^{* *}$ & $0.875^{* *}$ & $-0.862^{* *}$ & -0.132 \\
Testes weight & & $0.624^{* *}$ & $0.471^{*}$ & $0.617^{* *}$ & $-0.555^{*}$ & -0.140 \\
Semen volume & & $0.537^{*}$ & $0.609 * *$ & $-0.527^{*}$ & -0.234 \\
Sperm concentration & & & $0.887^{* *}$ & $-0.861^{* *}$ & -0.207 \\
$\begin{array}{l}\text { Sperm motility } \\
\text { Percentage of abnormal sperms }\end{array}$ & & & & $-0.828^{* *}$ & -0.284 \\
\end{tabular}

$* \mathrm{P}<0.05, * * \mathrm{P}<0.01$.

Table 5 shows the correlation coefficients between the egg fertility, testes weight, semen volume, sperm concentration, sperm motility, percentage of abnormal sperms and semen $\mathrm{pH}$ in the second generation of the full-sib mating group. The egg fertility showed significant correlation, i. e., correlation coefficients above 0.5 , with the testes weight, semen volume, sperm concentration sperm motility and percentage of abnormal sperms. In particular, correlations between the egg fertility and sperm characteristics (sperm concentration, sperm motility and percentage of abnormal sperms) were significantly high. However, no significant correlation was obtained between the egg fertility and semen $\mathrm{pH}$.

\section{Discussion}

In the present experiment, male reproductive ability was investigated in association with the reduction in egg fertility by inbreeding. The inbred male quail which caused the reduction of egg fertility were found to have decreased testes weight, semen volume, sperm concentration and sperm motility, and an increased abnormal sperm count.

Semen consists of seminal plasma and sperm. The seminal plasma is known to be produced in the epididymis, deferential and accessory reproductive glands. Spermatogenesis occurs within the seminiferous tubules. The occurrence of regressive changes in the male reproductive organs seen in the full-sib mating group such as the decrease in the testes weight suggests that the decrease in the semen volume and sperm concentration as a result of inbreeding are due to inhibition of seminal plasma production and spermatogenesis.

In poultry the fluid secreted from accessory reproductive glands is regarded as being closely related to sperm activity ${ }^{12-14}$. If the loss of sperm motility by full-sib mating is assumed to be associated with the fluid of the accessory reproductive glands, the decrease in the volume and quality of the fluid may be considered to bring about the loss of sperm activity.

The increased appearance of abnormal sperms is known in poultry to induce a reduction in egg fertility ${ }^{15}$. ELJACK and SYKES ${ }^{18)}$ reported the increased appearance 


\section{Sato, Sato and Ino}

of abnormal sperms by administration of a dithiobiurea derivative, which inhibits the secretion of gonadotropic hormones from the pituitary gland. They speculated that the inhibited secretion of gonadotropic hormones by administration of the dithiobiurea derivative decreases the secretion of androgen to result in the disturbance of normal spermatogenesis. In a later experiment (unpublished), it is assumed from the morphological examination of Leydig cells that the androgen level may have decreased in the inbred males which had increased abnormal sperms.

The above results seem to indicate that an overall reduction or disorder in male reproductive ability such as morphological and functional abnormalities of testes and sperms, occurred in the inbred male quail and seriously affected the egg fertility in the full-sib mating group. It was also considered that the overall reduction or disorder in male reproductive ability in the inbred males resulted from an increase in homozygosity due to a decrease in heterozygosity.

This investigation was supported by a Grant in Aid for the Fundamental Scientific Research of the Ministry of Education, Government of Japan (Grant No. 58480074).

\section{References}

1) Sittmann, K., H. Abplanalp and R. A. Fraser, Genetics, 54: 371-379. 1966.

2) Shinjo, A., Y. Mizuma and S. Nishida, Japan. Poult. Sci., 8: 231-237. 1971.

3) Kulenkamp, A. W., C. M. Kulenkamp and T. H. Coleman, Poult. Sci., 52: 1240-1246. 1972.

4) Kawahara, T., Ann. Rep. Nat. Inst. Genet., 23: 126-127. 1972.

5) Lucotte, G., Ann. Biol., 14: 167-182. 1975.

6) Narayan, A. D., Sabrao J., 7: 201-210. 1975.

7) Oкамото, S. and T. Matsuo, Agr. Bull. Saga Univ., 46: 9-16. 1979.

8) Maeda, Y., M. Ijuin, T. Hashiguchi and M. Taketomi, Japan. Poult. Sci., 18: 86-97. 1981.

9) Sato, K., T. Yamamoto, S. Ito, H. Kobayashi and T. Ino, Jpn. J. Zootech. Sci., (in press).

10) Kobayashi, S., S. Okamoto and T. Matsuo, Arg. Bull. Saga Univ., 32: 89-95. 1971.

11) Clark, C. E. and C.S. Shaffner, Poult. Sci., 39: 1213-1220. 1960.

12) Nishiyama, H., K. Ogawa and Y. Nakanishi, Mem. Fac. Agric. Kagoshima Univ., 8: 355366. 1971.

13) Fujihara, N. and H. Nishiyama, Poult. Sci., 55: 2415-2420. 1976.

14) Terada, T. and M. Watanabe, Jpn. J. Zootech. Sci., 49: 47-53. 1978.

15) Sаекі, Y., Poult. Sci., 39: 1351-1361. 1960.

16) ElJACK, M. H. and A.H. Sykes, J. Reprod. Fertil., 10: 79-84. 1965. 
Egg Fertility and Male Reproductive Ability

\title{
きょうだい交配による日本ウズラの受精率と 精巣重量および精液性状との関保
}

\author{
佐藤勝紀・佐藤 進・猪 貴義 \\ 岡山大学農学部，岡山市 700
}

本研究は，近交による日本ウズラの受精率低下の原因 を明らかにするために，近交によっておこる受精率の低 下と雄の性機能との関係について検討した。実験に使用 した日本ウズラは，近交群と無作為交配群の1,2 世代で ある。

1. 近交群の受精率は 2 世代目で急激な低下がみら れ，無作為交配群との間に有意差が認められた.

2. 近交群では無作為交配群に比較して, 精巣重量, 精液量, 精子濃度, 精子の運動性はすべて減少し,これ に対して奇形精子の出現頻度は増加した.しかしながら， 精液 $\mathrm{pH}$ には両群閒で差異が認められなかった。
3. 受精率の高い群では受精率の低い群に比べて, 精 巣重量, 精液量, 精子濃度, 精子の運動性, 陭形精子の 出現頗度はいずれもすぐれた值を示した。

4. 相笑係数は，受精率と精巣重量の間では+0.535， 受精㴶と精液量の間では+0.547, 受精察と精子濃度の間 では+0.824, 受精察之精子の運動性の間では+0.875, 受精率と奇形精子の出現頻度の間ではー0.862 となり, いずれも有意な值が詂められた.

5. 以上の結果から，近交による受精率の低下は雄で の造精機能全体の低下，障害に起因するものと考允られ 万. 日畜会報，55(1)：45-51，1984 